\title{
Suicide By an Elderly Patient with Ischemic Heart Disease: Case Report
}

\author{
İskemik Kalp Hastalığı Olan Yaşlı Hastada Özkıyım: Olgu Sunumu
}

\author{
Mehmet Tahir GÖKDEMiR, ${ }^{1}$ Özgür SÖĞÜT, ${ }^{1}$ Halil KAYA, ${ }^{1}$ Mehmet Özgür ERDOĞAN, ${ }^{2}$ Mahmut TAŞ ${ }^{3}$ \\ 'Department of Emergency Medicine, Harran University, Faculty of Medicine, Şanlıurfa; \\ ${ }^{2}$ Department of Emergency Medicine, Sanliurfa State Hospital, Şanlıurfa; \\ ${ }^{3}$ Department of Emergency Medicine, Diyarbakır State Hospital, Diyarbakır, Turkey
}

\begin{abstract}
SUMMARY
Older people are generally more successful than younger adults in committing suicide. Successful treatment of depression and chronic illness reduces the incidence of suicidal behavior in the elderly population. We present a case of successful suicide case by a patient who underwent coronary artery bypass graft surgery after an acute myocardial infarction.
\end{abstract}

Key words: Depression; elderliness; ishemic heart disease; suicide.

\section{ÖZET}

Yaşlı kişilerin özkıyım girişimleri genç insanlara göre çok daha ölümcüldür. Kronik hastalığı bulunan yaşılıarda depresyonun etkin tedavisi özkıyım eğilimi oranını azaltır. İskemik kalp hastalığı zemininde gelişen akut miyokard enfarktüsü sonrası baypas ameliyatı uygulanan ve özkıyım girişimi sonucu hayatını kaybeden olgu sunuldu.

Anahtar sözcükler: Depresyon; yaşılık; iskemik kalp hastalığı; özkıyım.

\section{Introduction}

The elderly generally commit suicide at a much higher success rate than younger persons, in many countries higher than any other portion of the population. ${ }^{[1]}$ Older people who commit suicide are less likely to have discussed their plans beforehand, and nonviolent deaths from suicide in the elderly may be mistakenly attributed to illness. In addition, distinctive stresses accompany late life, including retirement, loss of loved ones, social isolation, and an increasing disability burden, each of which has been suggested as a risk factor for suicide in the elderly. ${ }^{[2]}$ Herein, we describe a successful suicide case in an elderly patient who underwent coronary artery bypass graft surgery after an acute myocardial infarction.

\section{Case Report}

A 78-year-old male was admitted to the emergency department (ED) for chest pain. After cardiac testing (e.g., electrocardiogram, serum cardiac markers), he was diagnosed with an acute myocardial infarction (MI). The initial treatment of acute $\mathrm{MI}$ in the ED was provided for the patient and he was consulted with the cardiology department.

The patient was hospitalized in the coronary intensive care unit. Surgical treatment was indicated and he underwent coronary artery bypass graft surgery. He had no psychiatric disorder in his medical history, whereas he presented with symptoms of depression on the first day of postoperative

Submitted (Geliş tarihi): September 24, 2011 Accepted (Kabul tarihi): December 16, 2011 Published online (Online baskı): March 5, 2012

Correspondence (Iletişim): Mehmet Tahir Gökdemir, M.D. Harran Üniversitesi Tıp Fakültesi, Acil Tıp Anabilim Dalı, Şanlıurfa, Turkey

e-mail (e-posta): tahirgokdemir@mynet.com 


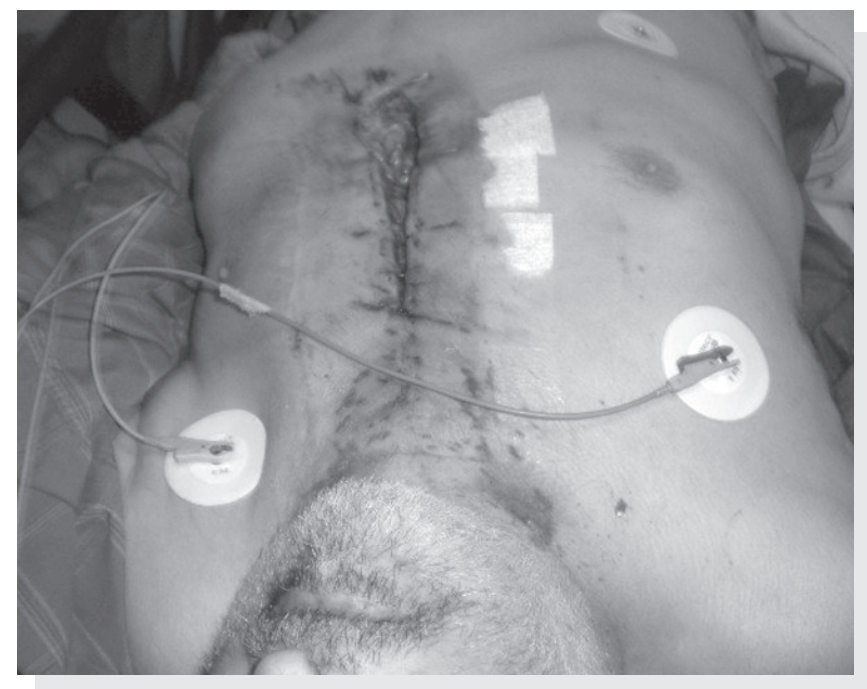

Figure 1. Dehisced of sutures on the sternal region.

follow-up and required a psychiatric consultation. Selective serotonin re-uptake inhibitor (SSRI) with tricyclic antidepressants (i.e., amitriptyline and sertraline) were added to the therapy.

At 10 a.m., next day, the patient jumped from the fourth floor of the hospital to commit suicide and was brought into to the ED after the fall. He had a pupillary reflexes but no spontaneous respiration or circulation. His Glasgow Coma Scale (GCS) was 3. The sutures on the sternal region had dehisced (Fig. 1) and evisceration had occurred on the right lower quadrant of the abdomen (Fig. 2). Although cardiopulmonary resuscitation was provided, the patient did not survive. On the autopsy report, the cause of death was attributed to aortic rupture, liver laceration, pulmonary contusion, and hemorrhagic shock.

\section{Discussion}

Factors associated with an increased suicide risk include modifiable conditions such as mood disorders, alcoholism, and substance abuse, as well as fixed characteristics such as male gender and advancing age. ${ }^{[3,4]}$ Although the elderly generally succeed at suicide more than other portions of the population, suicide in the elderly generally receives less attention in the medical literature and news media than suicide in younger adults. ${ }^{[5]}$ Blazer et al. ${ }^{[6]}$ reported that patients with congestive heart failure were twice as likely to shoot themselves and half as likely to hang themselves. Our patient had no history of psychiatric disease until his heart disease was diagnosed. He was married and had children. None of the family members reported to have suffered from any psychiatric illness in the past.

$\mathrm{Ml}$ is associated with an increased risk of anxiety, depressi-

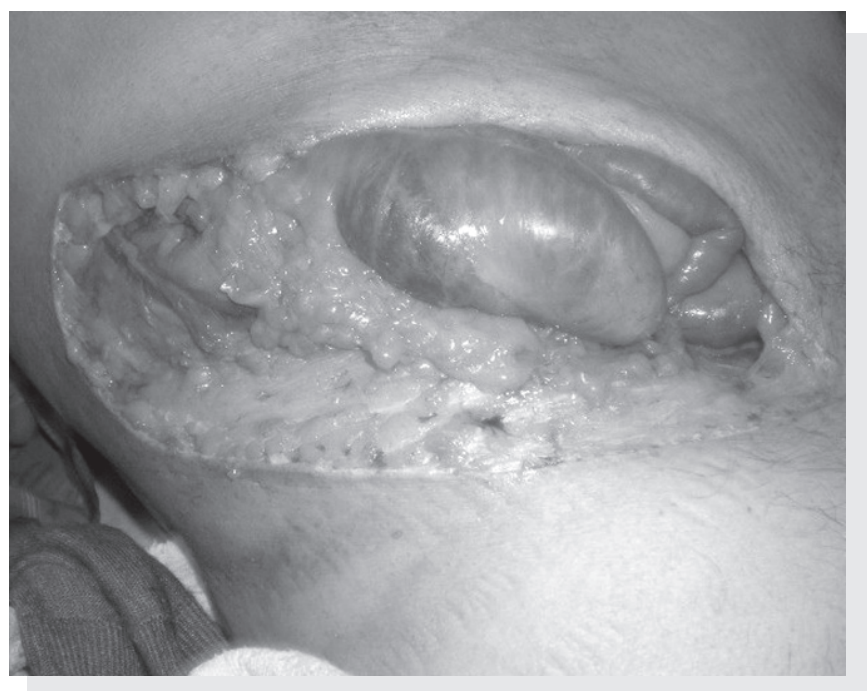

Figure 2. Evisceration in the right lower quadrant of the abdomen.

on, low quality of life, and all-cause mortality. Whether MI is associated with an increased risk of suicide is unknown. ${ }^{[7]}$ Larsen et al. ${ }^{[8]}$ reported that suicide risk is highest during the first month after discharge for an $\mathrm{Ml}$ in patients with no history of psychiatric illness. Heok et al. ${ }^{[9]}$ reported that depressed elderly with chronic pain are prone to suicidal ideation. Depression is a risk factor for cardiovascular disease and mortality from coronary heart disease. In this case, the patient had ischemic heart disease and a history of MI for 1 year. Psychiatric symptoms appeared after the diagnosis of ischemic heart disease, and the patient did not use regular psychiatric treatment. The patient committed suicide during the postoperative follow-up in the coronary intensive care unit. We thought that the patient's completed suicide was associated with an acute stress reaction after the bypass surgery underlying emotional response to the serious coronary heart disease.

\section{Conclusion}

An important clinical implication of this case is that clinicians should recognize that patients with depression are at increased risk for suicidal behavior, even in the absence of other more common mental disorders. Successful treatment of depression and severe illness reduces the incidence of suicidal behavior in the elderly. Elderly with serious coronary heart disease must consult with a psychiatrist and appropriate treatment protocols must be followed. Healthcare personnel must be trained to support hospitalized patients and patients with serious chronic illnesses such as heart disease.

\section{Conflict of Interest}

The author(s) declare(s) no conflict of interest related to this work. 


\section{References}

1. Cantor $\mathrm{CH}$, Baume PJ. Suicide prevention: a public health approach. Aust N Z J Ment Health Nurs 1999;8:45-50.

2. Conwell Y, Duberstein PR. Suicide in elders. Ann N Y Acad Sci 2001;932:132-50.

3. Angst J, Angst $F$, Stassen $\mathrm{HH}$. Suicide risk in patients with major depressive disorder. J Clin Psychiatry 1999;62:57-62;76, 113-6.

4. Conwell Y. Suicide prevention in later life: a gass half full, or half empty? Am J Psychiatry 2010;167:102.

5. Tueth MJ, Zuberi P. Life-threatening psychiatric emergen- cies in the elderly: overview. J Geriatr Psychiatry Neurol 1999;12:60-6.

6. Blazer DG, Bachar JR, Manton KG. Suicide in late life. Review and commentary. J Am Geriatr Soc 1986;34:519-25.

7. Juurlink DN, Herrmann N, Szalai JP, Kopp A, Redelmeier DA. Medical illness and the risk of suicide in the elderly. Arch Intern Med 2004;164:1179-84.

8. Larsen KK, Agerbo E, Christensen B, Søndergaard J, Vestergaard M. Myocardial infarction and risk of suicide: a population-based case-control study. Circulation 2010;122:2388-93.

9. Heok KE, Ho R. The many faces of geriatric depression. Curr Opin Psychiatry 2008;21:540-5. 